\title{
Acute renal failure in early life
}

\author{
N. K. GRIFFIN, J. McELNEA, and T. M. BARRATT \\ From the Hospital for Sick Children, Great Ormond Street, London
}

\begin{abstract}
Griffin, N. K., McElnea, J., and Barratt, T. M. (1976). Archives of Disease in Childhood, 51. 459. Acute renal failure in early life. Data are presented on 25 children under 2 years of age with acute renal failure treated by peritoneal dialysis. The clinical features, treatment, complications, and outcome of the illnesses are described. $22(88 \%)$ survived, and though the incidence of serious complications during the illness was high, most regained full health and normal renal function.
\end{abstract}

In spite of technical advances, acute renal failure $(A R F)$ in adults remains a serious condition with a substantial mortality (Stott et al., 1972). In young children, however, better results can be obtained (Gordillo-Paniagua, 1966), but the problem is infrequent in the United Kingdom, and little systematic experience has been presented (Barratt, 1971). At the Hospital for Sick Children, London, all children requiring dialysis have been treated on a single ward since 1969, and we report here our experience of those under 2 years of age who were treated by peritoneal dialysis, and discuss the causes of their illness, the complications, and the outcome of treatment.

\section{Patients and results}

Twenty-five children under 2 years of age were referred with acute oliguric renal failure, and were subsequently treated by peritoneal dialysis because of uraemia, hyperkalaemia, or hypernatraemia, during the 5 -year period from March 1969. A further 12 children of this age developed ARF in hospital after cardiac surgery. They were treated in the intensive care unit of the cardiac department, and 10 died. This problem is reviewed elsewhere and the children are not included in this survey (Barratt, 1973). The causes of ARF in these children fall into three main categories shown in Table $I$.

I. Intravascular coagulation. In the first group of 12 children (Table II) there was evidence of diffuse intravascular coagulation diagnosed on the evidence of a low platelet count, a high titre of fibrin degradation products in the serum, and anaemia with red cell fragmentation in association with uraemia. In 8 children (group Ia) no cause could be found; the clinical

Received 12 September 1975.
TABLE I

Children aged less than 2 years with ARF treated by peritoneal dialysis at the Hospital for Sick Children, London, 1969-74

\begin{tabular}{l|c}
\hline \multicolumn{1}{c|}{ Aetiology } & $\begin{array}{c}\text { No. of } \\
\text { children }\end{array}$ \\
\hline $\begin{array}{l}\text { I. Intravascular coagulation } \\
\text { (a) Haemolytic-uraemic syndrome } \\
\text { (b) Esch. coli septicaemia }\end{array}$ & 8 \\
II. Structural malformations & 4 \\
(a) Urethral valves \\
(b) Other \\
III. Presumed acute tubular necrosis \\
(a) Isolated \\
(b) With renal venous thrombosis & 5 \\
& \\
\hline
\end{tabular}

features of their illness were typical of the idiopathic haemolytic-uraemic syndrome (HUS) (Lieberman, 1972). In the remaining 4 children there was evidence from blood culture of an Esch. coli septicaemia (group Ib).

The children with HUS (group Ia) were aged 4 to 22 months. They were all severely anaemic, despite the fact that some had been transfused before transfer, and were usually fluid overloaded on arrival at the hospital. 4 of these children convulsed. All had raised FDP titres and were treated with heparin. They required an average of 6.5 days on dialysis. All these children survived and in none was there evidence of renal disease at the time of discharge. These patients account for $44 \%$ ( 8 of 18 ) of our experience of children with HUS during this period: the remainder were either over 2 years of age or did not need dialysis.

The 4 infants with Esch. coli septicaemia (Group Ib) were all male and less than 2 months of age, were severely ill, and all required assisted ventilation up to 4 
TABLE II

Children with disseminated intravascular coagulation treated by dialysis

\begin{tabular}{|c|c|c|c|c|c|c|c|c|c|c|c|c|}
\hline \multirow[b]{2}{*}{ Case no. } & \multicolumn{8}{|c|}{ Group Ia-(haemolytic-uraemic syndrome) } & \multicolumn{4}{|c|}{ Group Ib (septicaemia) } \\
\hline & 1 & 2 & 3 & 4 & 5 & 6 & 7 & 8 & 9 & 10 & 11 & 12 \\
\hline Age (m) & 7 & 8 & 22 & 13 & 4 & 6 & 9 & 17 & 1 & 0.5 & 1 & $0 \cdot 8$ \\
\hline Sex & $\mathbf{M}$ & $\mathrm{F}$ & $\bar{M}$ & $\mathrm{M}$ & $M^{*}$ & $M$ & $\mathbf{M}$ & $\mathbf{F}$ & $\dot{M}$ & $M$ & $\dot{M}$ & $\mathbf{M}$ \\
\hline Hydration* & + & $\mathbf{N}$ & + & + & + & + & $\mathbf{N}$ & + & + & $\mathrm{N}$ & - & + \\
\hline Blood urea & & & & & & & & & & & & \\
\hline$(\mathrm{mg} / 100 \mathrm{ml})$ & 246 & 164 & 357 & 210 & 273 & 273 & 375 & 193 & 350 & 332 & 335 & 354 \\
\hline Plasma K $+(\mathrm{mEq} / \mathrm{l})$ & $4 \cdot 6$ & $4 \cdot 1$ & $5 \cdot 1$ & $6 \cdot 2$ & $4 \cdot 9$ & $4 \cdot 5$ & $4 \cdot 1$ & $3 \cdot 9$ & $4 \cdot 6$ & $7 \cdot 5$ & $8 \cdot 0$ & $6 \cdot 9$ \\
\hline $\begin{array}{l}\text { Haemoglobin } \\
(\mathrm{g} / \mathrm{dl})\end{array}$ & & $4 \cdot 6$ & $5 \cdot 0$ & 2.9 & 4.7 & & & $8 \cdot 0$ & & & & \\
\hline $\begin{array}{l}\text { (g/dl) } \\
\text { Platelets }\end{array}$ & 3.6 & $4 \cdot 6$ & $5 \cdot 0$ & $2 \cdot 9$ & $4 \cdot 7$ & $7 \cdot 4$ & $6 \cdot 3$ & $8 \cdot 0$ & $8 \cdot 8$ & $13 \cdot 9 t$ & 6.9 & $7 \cdot 5$ \\
\hline$\left(\mathrm{mm}^{-3} \times 10^{-3}\right)$ & 27 & 16 & 15 & 18 & 55 & 70 & 74 & 50 & 52 & 18 & 40 & 140 \\
\hline Blood culture & - & - & - & - & - & - & - & - & + & + & + & + \\
\hline Convulsions & + & - & - & - & - & + & + & + & + & - & + & + \\
\hline Ventilator care & - & - & - & - & - & - & - & - & + & + & + & + \\
\hline Days on dialysis & 13 & 7 & 7 & 3 & 2 & 13 & 3 & 7 & 3 & 1 & 1 & 9 \\
\hline Peritonitis & + & + & - & - & - & - & - & - & + & - & - & - \\
\hline $\begin{array}{l}\text { Discharge urea } \\
(\mathrm{mg} / 100 \mathrm{ml})\end{array}$ & 22 & 32 & 41 & 40 & 28 & 20 & 28 & 34 & Died & 31 & 15 & 21 \\
\hline
\end{tabular}

$\star+$, overhydration; $N$, normal hydration; - , dehydration.

tTransfused.

days. 3 convulsed. However, renal function improved more rapidly when the septicaemia was treated than did that in the HUS group, and dialysis was necessary for an average of 3.5 days only. Esch coli. was grown from both blood and urine cultures of all 4 infants, but none of them had meningitis. In the patient who died (Case 9), the septicaemia was associated with necrotizing enterocolitis; peritoneal dialysis was complicated by a perforated caecum and $76 \mathrm{~cm}$ of gut was resected. At necropsy examination there were multiple renal abcesses. The other infants in this group had no urological abnormality and regained normal renal function, but Case 11 had a mild residual hemiparasis.

II. Urological malformations (Table III). The most common urological malformation encountered was posterior urethral valves (Group IIa). 5 uraemic infants with urethral valves were treated with short periods of dialysis for less than 2 days in order to prepare them for urological surgery, usually temporary bilateral nephrostomies. None required dialysis after relief of their urinary obstruction. Of the patients in this group 2 convulsed and one required ventilatory support. One infant (Case 4) was born at 33 weeks' gestation and weighed only $2 \mathrm{~kg}$ on admission; in addition to posterior urethral values he had salt-losing congenital adrenal hyperplasia and a ventricular septal defect.

In group IIb one boy (case 19) had bilateral renal dysplasia and was dialysed for 3 days before he was stabilized on a diet with a controlled protein and sodium content. A girl (Case 18) was dialysed preparatory to an open renal biopsy because plasma creatinine was $8 \mathrm{mg} / 100 \mathrm{ml}$ though blood urea was only $85 \mathrm{mg} / 100 \mathrm{ml}$. Biopsy confirmed the diagnosis of congenital polycystic

TABLE III

Children with structural malformation of urinary tract treated by dialysis

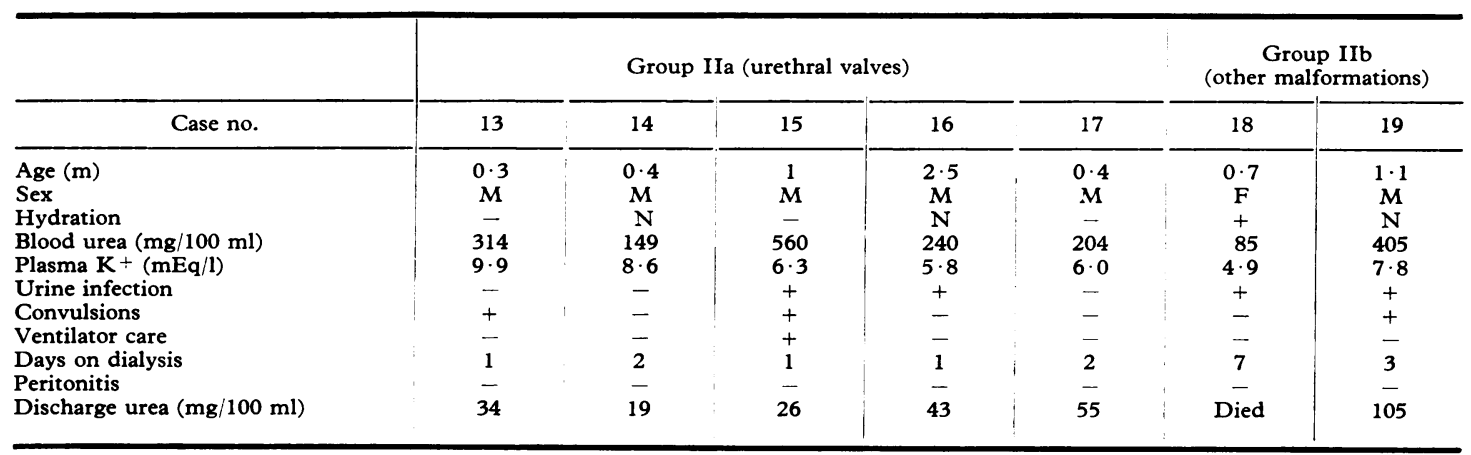


disease that had been suspected on intravenous urography; she subsequently died.

III. Presumed acute tubular necrosis. The 6 children in group III were believed to have had acute tubular necrosis (ATN) (Table IV). Their ages ranged from 0.7 to 20 months. In 5 of these patients, the illness followed severe dehydration or electrolyte disturbance, but in the sixth the aetiology was unclear. 2 infants were presumed to have had renal venous thrombosis as well on the basis of macroscopical haematuria, thrombocytopenia, and presence of firm enlarged kidneys. One of these children (Case 25) had a clinical diagnosis of bilateral renal venous thrombosis but survived with good renal function; he has been previously reported (Counahan, 1974). All the children in the group survived except Case 24 who had a subarachnoid haemorrhage on the day before admission. 2 hypernatraemic infants in this group convulsed. These children required only short periods of dialysis before renal function returned.

\section{Discussion}

The data illustrate the low mortality with treatment of ARF in infants. Only 3 children (12\%) died, and 2 of these had other severe disease; the third had congenital polycystic disease. Most of the rest have normal renal function.

The majority of our patients were at the younger end of the age range discussed: only 4 patients (16\%) were over one year old, $13(52 \%)$ were under 2 months, and 9 (36\%) were under one month of age. 2 babies had been born before term and required specialized preterm baby care in addition to other treatment.

The problems in managing infants with renal failure differ from those found in older patients. Fluid overload is better tolerated and pulmonary oedema was not observed. Hyperkalaemia was a common finding and was occasionally severe but was better tolerated than is usual in older patients. On the other hand, 6 of the patients (24\%) required mechanical ventilation for periods of up to 4 days. 12 patients $(48 \%)$ convulsed at some stage in their illness, usually attributable to their uraemic state, hyponatraemia, or most commonly hypocalcaemia. Plasma calcium concentration was below $9 \mathrm{mg} / 100 \mathrm{ml}$ in all but 2 of our patients; and in $9(36 \%)$ it was below $7 \mathrm{mg} / 100 \mathrm{ml}$; hypocalcaemia was more severe in the younger children. In 2 patients hypernatraemia was a contributory factor in the pathogenesis of the tubular necrosis and cerebral complications.

The mainstay of the dietary management of ARF in infants is the use of milk formulae with the low protein and sodium concentrations of breast milk, which also minimizes potassium and phosphate intake and metabolic hydrogen ion production. Despite the fact that uraemia had been recognized before transfer in all these children, many were still being fed on a high-protein, high salt diet of a cow's milk preparation. The adverse effects of the latter dietary regimens in infants with renal insufficiency are obvious and have been repeatedly stressed yet seem insufficiently appreciated in clinical paediatric practice (Barratt, 1971).

Of the 15 children requiring dialysis for more than 3 days, 5 had peritoneal infection, 3 bacterial, one fungal, and one mixed. The incidence of peritoneal infection increased with time: the mean duration of dialysis in those infected patients was 10 days, compared with 4 days for the whole group.

All patients required radiological investigation of the urinary tract except for those with the haemolytic-uraemic syndrome. This was deferred until the state of hydration had been restored but

\section{TABLE IV}

Children with presumed acute tubular necrosis treated by dialysis

\begin{tabular}{|c|c|c|c|c|c|c|}
\hline \multirow[b]{2}{*}{ Case no. } & \multicolumn{4}{|c|}{ Group IIIa (presumed acute tubular necrosis) } & \multicolumn{2}{|c|}{$\begin{array}{c}\text { Group IIIb (renal venous } \\
\text { thrombosis) }\end{array}$} \\
\hline & 20 & 21 & 22 & 23 & 24 & 25 \\
\hline $\begin{array}{l}\text { Age }(\mathrm{m}) \\
\text { Sex } \\
\text { Preceding diarrhoea } \\
\text { Hydration } \\
\text { Blood urea }(\mathrm{mg} / 100 \mathrm{ml}) \\
\text { Plasma } \mathrm{Na}+(\mathrm{mEq} / \mathrm{l}) \\
\text { Plasma } \mathrm{K}+(\mathrm{mEq} / \mathrm{kl}) \\
\text { Convulsions } \\
\text { Ventilator care } \\
\text { Days on dialysis } \\
\text { Peritonitis } \\
\text { Discharge urea }(\mathrm{mg} / 100 \mathrm{ml})\end{array}$ & $\begin{array}{l}20 \\
\mathrm{M} \\
+ \\
- \\
127 \\
137 \\
3 \cdot 6 \\
- \\
- \\
+8 \\
+ \\
37\end{array}$ & $\begin{array}{l}0 \cdot 7 \\
F \\
+ \\
+ \\
273 \\
138 \\
8 \cdot 3 \\
- \\
- \\
-2 \\
16\end{array}$ & $\begin{array}{l}1 \cdot 3 \\
\mathrm{M} \\
+ \\
+ \\
345 \\
169 \\
5 \cdot 9 \\
+ \\
\overline{4} \\
\overline{31}\end{array}$ & $\begin{array}{l}11 \\
\mathrm{M} \\
- \\
\mathrm{N} \\
330 \\
137 \\
7 \cdot 7 \\
- \\
\overline{17} \\
+ \\
43\end{array}$ & $\begin{array}{c}3 \\
F \\
+ \\
+ \\
240 \\
168 \\
4 \cdot 0 \\
+ \\
+ \\
1 \\
- \\
\text { Died }\end{array}$ & $\begin{array}{l}1 \\
M \\
+ \\
- \\
405 \\
133 \\
7 \cdot 3 \\
- \\
-4 \\
- \\
14\end{array}$ \\
\hline
\end{tabular}


not necessarily until the uraemia had been corrected. Hydronephrosis due to urethral valves was shown in 5 patients, and required surgical correction (Williams, 1974; R. J. Levinsky, T. M. Barratt, and D. I. Williams, in preparation). Liaison with urological surgeons is essential during the assessment and treatment of these patients.

Although peritoneal dialysis in infants is technically simple, it is but one aspect of the care of children with renal failure. Such children should be referred to specialist units as soon as oliguria $(<0.5 \mathrm{ml} / \mathrm{kg}$ body weight per $\mathrm{h})$ resistant to volume repletion and intravenous frusemide ( $5 \mathrm{mg} / \mathrm{kg}$ body weight) is recognized. Their successful management requires a paediatrician experienced in dialysis, supported by a full range of paediatric facilities. The co-operation of urological, radiological, anaesthetic, and pathological department orientated to the care of children is essential. These must work in harmony with specialist paediatric nursing staff experienced in the management of peritoneal dialysis. For these reaons the management of the infants should be concentrated in children's hospitals or large paediatric departments that have the full range of paediatric subspeciality services.

\section{REFERENCES}

Barratt, T. M. (1971). Renal failure in the first year of life. British Medical Bulletin, 27, 115.

Barratt, T. M. (1973). Post-operative complications of children with congenital heart disease. Bulletin of the Association of European Paediatric Cardiologists, 9, 54.

Counahan, R. (1974). Bilateral renal venous thrombosis. Archives of Disease in Childhood, 49, 68.

Gordillo-Paniagua, G. (1966). Acute renal failure in newborns and infants. Proceedings of the 3rd International Congress of Nephro$\log y$, p. 13. Ed. by G. E. Schreiner. Karger, Basel.

Lieberman, E. (1972). Hemolytic-uremic syndrome. fournal of Pediatrics, 80, 1.

Stott, R. B., Cameron, J. S., Ogg, C. S., and Bewick, M. (1972)。 Why the persistently high mortality in acute renal failure? Lancet, 2, 75.

Williams, D. I. (1974). Obstructive uropathy: the urethra. Urology in Childhood (Supplement), p. 207. Ed. by D. I. Williams. Springer, Berlin.

Correspondence to Dr. T. M. Barratt, Department of Immunology, Institute of Child Health, 30 Guilford Street, London WC1N 1EH. 